\title{
Demonstration of Solar Heating and Cooling System using Sorption Integrated Solar Thermal Collectors
}

\author{
Corey Blackman ${ }^{1,2}$, Olof Hallström ${ }^{2}$ Chris Bales ${ }^{1}$ \\ ${ }^{1}$ Dalarna University, Borlänge, Sweden \\ ${ }^{2}$ Mälardalen University, Västerås, Sweden
}

\begin{abstract}
Producing cost-competitive small and medium-sized solar cooling systems is currently a significant challenge. Due to system complexity, extensive engineering, design and equipment costs; the installation costs of solar thermal cooling systems are prohibitively high. In efforts to overcome these limitations, a novel sorption heat pump module has been developed and directly integrated into a solar thermal collector. The module comprises a fully encapsulated sorption tube containing hygroscopic salt sorbent and water as a refrigerant, sealed under vacuum with no moving parts. A $5.6 \mathrm{~m}^{2}$ aperture area outdoor laboratory-scale system of sorption module integrated solar collectors was installed in Stockholm, Sweden and evaluated under constant re-cooling and chilled fluid return temperatures in order to assess collector performance. Measured average solar cooling COP was 0.19 with average cooling powers between 120 and $200 \mathrm{Wm}^{-2}$ collector aperture area. It was observed that average collector cooling power is constant at daily insolation levels above $3.6 \mathrm{kWhm}^{-2}$ with the cooling energy produced being proportional to solar insolation. For full evaluation of an integrated sorption collector solar heating and cooling system, under the umbrella of a European Union project for technological innovation, a 180 $\mathrm{m}^{2}$ large-scale demonstration system has been installed in Karlstad, Sweden. Results from the installation commissioned in summer 2014 with non-optimised control strategies showed average electrical COP of 10.6 and average cooling powers between 140 and $250 \mathrm{Wm}^{-2}$ collector aperture area. Optimisation of control strategies, heat transfer fluid flows through the collectors and electrical COP will be carried out in autumn 2014.
\end{abstract}

Keywords: solar cooling, absorption, integrated sorption collector, sorption heat pump

\section{Introduction}

Solar thermal cooling has difficulty emerging as an economically viable solution for small-scale systems mainly due to high investment costs and system complexity (Henning, 2007). Strategic R\&D requirements for increased market penetration of solar thermal cooling by 2020 should provide for small and medium- sized solar thermal cooling kits with 'plug-and-play' functionality. Additionally, high integration of solar thermal systems for both cooling (in the summer) and heating (in the winter) would increase year-round usage and therefore reduce overall system payback time. Enhanced control strategies and improved hydraulic concepts leading to electrical coefficients of performance $\left(\mathrm{COP}_{\mathrm{el}}\right)>10$ and augmented cost-performance relations are all seen as necessities to future growth of the solar heating and cooling sector (Stryi-Hipp et al., 2012). The COP is heavily dependent on system complexity, with the main competitive feature of a solar cooling system compared to a conventional compressor based system being the reduction in electricity consumption (Hallström et. al. 2014). A sorption integrated solar thermal collector has been developed in efforts to address the aforementioned market penetration limitations of solar thermal cooling systems.

\subsection{Sorption Integrated Collector}

The sorption integrated solar thermal collector is made up of 8 modules connected in series via their respective heat exchangers. The sorption module is a tubular heat pump that comprises two cylindrical parts; a reactor which contains the hygroscopic salt lithium chloride and a condenser/evaporator $(\mathrm{C} / \mathrm{E})$ which contains water as a refrigerant. The latter component may act as either condenser or evaporator depending on the flow direction 
of the refrigerant vapour within the module. The reactor is covered by a metallic solar absorber heat exchanger; with a selective surface coating on the upper side and pipes for heat transfer fluid flow on the lower side. The condenser/evaporator has a jacket heat exchanger to allow for heat transfer to and from a fluid in contact with its surface. During the day, the absorber and thus the reactor of the sorption module are heated by solar radiation while the condenser is shaded from the sun and cooled by a re-cooling fluid. There is no circulation of fluid in the solar absorber heat exchanger during the day (in summer). When the absorber temperature reaches the required level to provide the requisite pressure difference between reactor and condenser/evaporator, desorption begins, and refrigerant vapour evaporates from the salt in the reactor and condenses in the condenser/evaporator. This condensation heat is transported away by the re-cooling fluid and exhausted via a heat sink (dry cooler/ground source heat exchanger). This process is called desorption and continues with the drying of the salt in the reactor (i.e. strengthening of the salt solution) until radiation levels are too low to maintain it. At sunset the reactor is cooled down via a flow of re-cooling fluid. As the reactor cools, the internal pressure falls causing the condensed refrigerant in the condenser/evaporator (now acting as an evaporator) to evaporate producing a chilling effect, this process is called absorption. Chilled fluid can thus be obtained directly from the evaporator heat exchanger of the collector modules. This chilled fluid may be stored (for daytime use) and/or serve the cooing load during the night.

The sorption modules that comprise the collectors are connected in series where the solar absorber heat exchangers of each module are interconnected. In addition, the jacket heat exchangers of the condenser/evaporator component of each module are connected together (Blackman and Bales, 2014). Therefore each collector has two separate hydraulic loops, one for the reactor heat exchangers of the modules and the other for the condenser/evaporator heat exchangers of the modules.

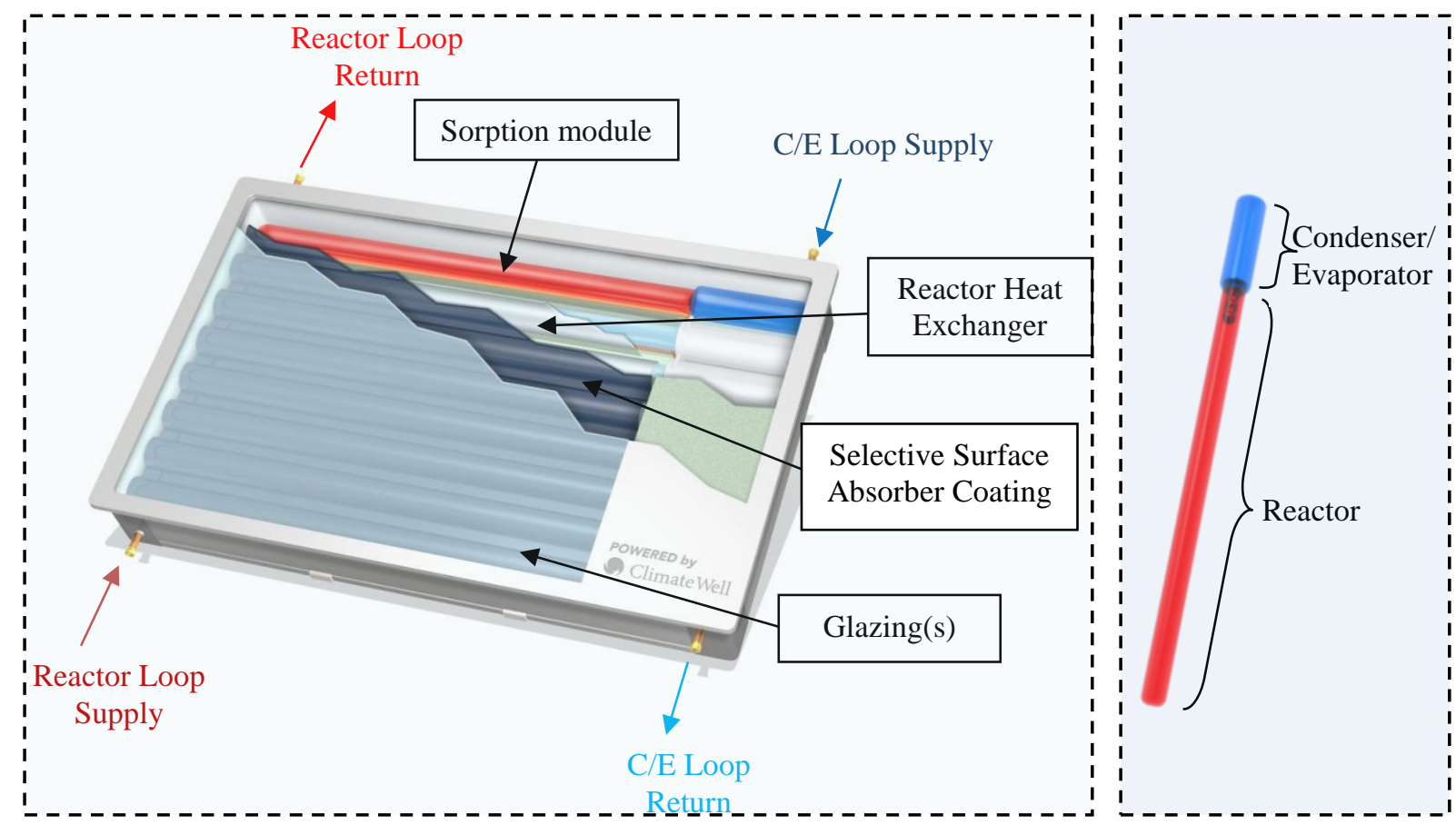

Fig. 1: Left: diagram of sorption module integration into the solar thermal collector and hydraulic loop connections. The solar absorber, with its own welded pipes, is in direct contact with the reactor of the sorption module. Right: diagram of a sorption module.

\subsection{Sorption Integrated Collector System Operation}

Overall, the sorption integrated solar thermal collector system has three (3) primary modes of operation; two modes in the summer and one in the winter. In winter, the system functions like a conventional solar thermal installation where when solar radiation heats the collectors' absorber to a useful temperature a pumped flow of heat transfer fluid is commenced to capture the thermal energy for heat supply and/or storage. If the absorber temperature falls below a useful level then the pump is stopped, terminating the flow of heat transfer fluid to the absorber heat exchanger until sufficiently high temperatures are obtained to recommence pump operation.

In summer, during the day, the system operates in desorption mode while at night it is shifted over into the absorption mode where cooling is produced. In the period between desorption and absorption the absorber needs to be cooled down from between 80 and $120^{\circ} \mathrm{C}$ (typical desorption level temperatures) to around 30 to 
$40^{\circ} \mathrm{C}$ (typical absorption level temperatures), the resulting thermal energy may be recovered for domestic hot water (DHW) production in the summer period. This intermediate phase is given the name swap and improves overall system efficiency and cost effectiveness if DHW is required at the site of the solar heating and cooling installation.

\section{Installation Description}

\subsection{Laboratory-Scale Demonstration Installation}

The outdoor laboratory-scale installation consists of 4 sorption collectors with total aperture area $5.6 \mathrm{~m}^{2}$ with a design cooling capacity of $1.3 \mathrm{~kW}$ oriented due south with an inclination angle of $40^{\circ}$. The collectors were connected in parallel in two banks of two collectors each with hydraulics consisting of two loops, one for the reactor side of the collector and one for the condenser/evaporator side of the collector, each with a separate pump (see Figure 2). The reactor circuit has drain-back and its inlet is at the bottom of the collector while the condenser/evaporator circuit has no drain back and inlet is at the top of the collector. Each hydraulic loop is connected to a plate heat exchanger via a mixing valve. The plate heat exchanger's secondary side is connected to a $1 \mathrm{~m}^{3}$ water storage tank which is chilled to between 10 and $15^{\circ} \mathrm{C}$ by a ground source heat exchanger in a borehole. Using the mixing valves for each loop, a constant temperature control strategy was employed to provide reasonably constant re-cooling and chilled fluid inlet temperatures $\left( \pm 1^{\circ} \mathrm{C}\right)$ in order to evaluate collector performance at various temperature set points.

The installation has a simplified control system that automatically moves between the two primary modes of operation and the intermediate swap mode on a timed basis. The installation started in desorption mode at between 08:00 (mid-summer) and 09:00 (late summer) with desorption carried out until 18:00. Desorption was followed by a 20 minute 'swap' period where the reactors of the collectors were cooled from the high desorption temperatures to the required absorption temperature. Absorption was subsequently started at 18:20 and terminated at the point where cooling power dropped below 50W. All temperatures were measured via KType thermocouples with absorber temperatures measured in two places on each collector (one logged and one manually spot checked) and fluid flow temperatures directly on the wall of the copper piping (under the piping insulation). Volumetric flow rates in both reactor and condenser heat exchanger flow loops were measured by a vortex flow sensor. Solar irradiation measurements were carried out by a Kipp\&Zonen CMP10 pyranometer. All data were recorded with a datalogger at a 1 second sample interval. Outdoor measurement and evaluation was done for a 2 month test period (June 28 to August 28, 2013) in Stockholm, Sweden.

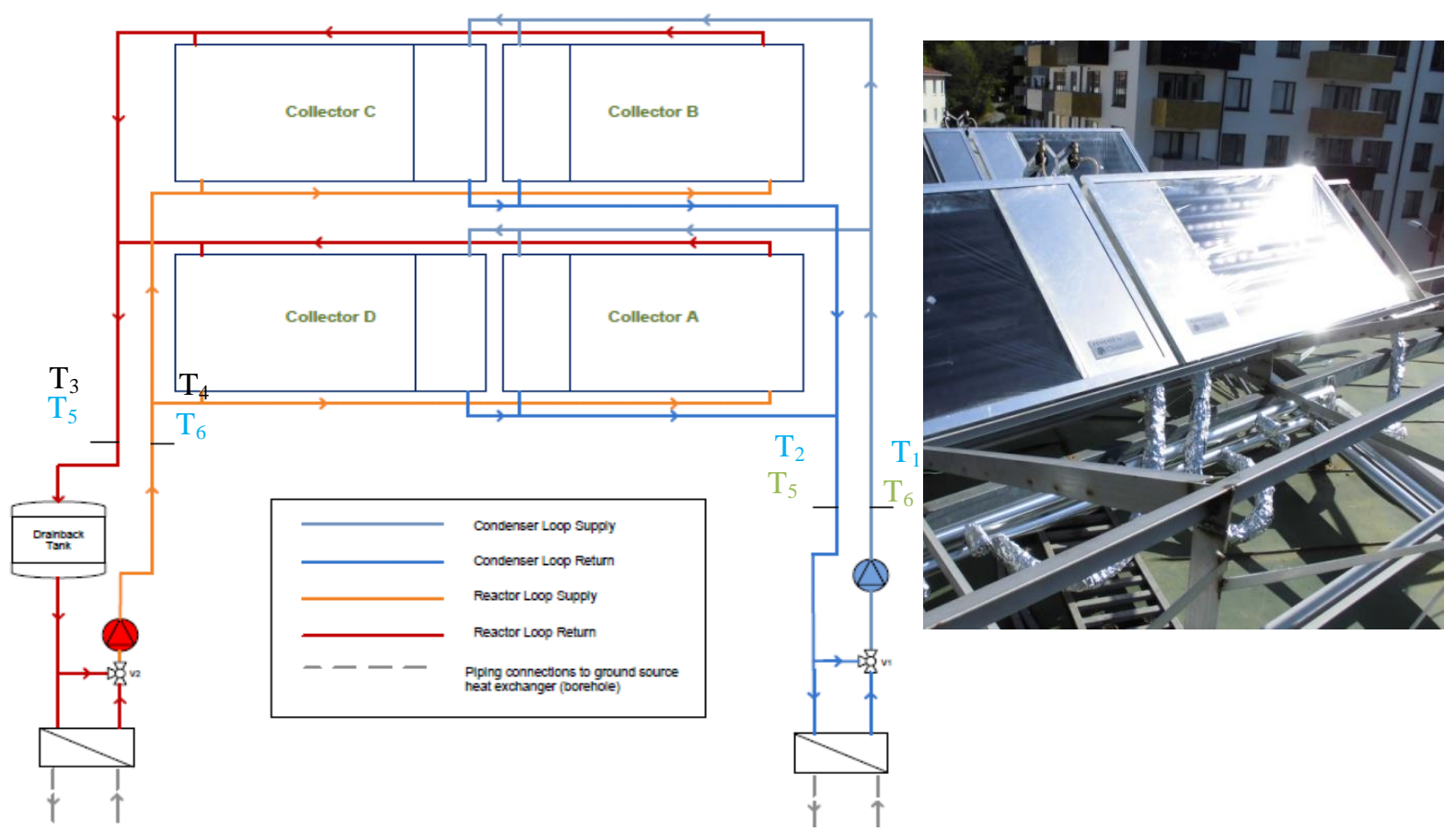

Fig. 2: Left: System schematic of laboratory-scale installation (temperature measurement points in green, blue and black correspond to the system operation in desorption, absorption and swap mode respectively). Right: photograph of glazed flat plate sorption integrated collectors in the laboratory-scale installation. 


\subsection{Large-Scale Demonstration Installation}

The large-scale installation consists of a solar field of $180 \mathrm{~m}^{2}$ aperture area where 130 sorption collectors are connected in parallel in 12 banks consisting of 8-13 collectors per bank. The collectors were oriented southwest with a $40^{\circ}$ tilt and the system's designed cooling capacity is $40 \mathrm{~kW}$. The principal collector loops are identical in principle to those of the laboratory-scale demonstration; however, the loops are connected to a dry cooler, heat storage tank and cold storage tank via a system of hydraulically separated loops of closely spaced $\mathrm{T}$ connections.

The hydraulic system comprises 10 Grundfos Magna3 pumps. The loops can be described as; collector loops, re-cooling loops, cooling loop, heating loop, cold storage loop and heat storage loop, heat supply loop and cooling supply loop. Each loop is actuated by a pump only (i.e. no controller actuated valves) and the flow rate of the heat transfer fluid can be adjusted by changing the head on the pumps (see Figure 3).

Cooling is delivered to the building's centralised cooling system that consists of 'pre-cooling' of indoor supply air and 'after-cooling' via ceiling mounted radiant cooling panels. The pre-cooling is done by $7 / 12^{\circ} \mathrm{C}$ (supply/return) water and the after-cooling is done by $13 / 18^{\circ} \mathrm{C}$ water. In order to have the highest possible return temperature to the collectors, the connection to the central HVAC system is made on the return of the 'after-cooling' circuit. At the installation site there is always a cooling demand at outdoor temperatures above $12^{\circ} \mathrm{C}$ where an estimated half of the cooling produced can be delivered during the night and the other half stored for daytime use. The cold store consists of a total of $13 \mathrm{~m}^{3}$ of water placed in three identical tanks.

The large-scale installation has an advanced control system in efforts to maximise the system's electrical COP, all pumps and fans are run stage-wise to reduce parasitic power consumption when the system is running below full capacity. The main operational modes of the system when running during the summer are:

\section{Desorption}

The desorption mode is governed by the incident solar irradiation, the absorber temperature of the collector field (average of 12 collectors, i.e. 1 collector per bank), the ambient temperature and the fluid supply temperature to the condenser/evaporator loop of the collector field. The first phase of the desorption mode occurs when the incident irradiation and absorber temperatures are sufficiently high; flow in collector loop C is started (see Figure 3). The second phase occurs when the flow in the recooling loop is started which is triggered by a more than $8^{\circ} \mathrm{C}$ above ambient temperature increase in the supply temperature of the fluid flowing in the collector loop $\mathrm{C}$ of the collector field. If the return temperature from the dry cooler is more than $4^{\circ} \mathrm{C}$ above the ambient temperature then the third phase of the desorption mode commences where the fans of the dry cooler start at the lowest speed. The fan operations are staged up or down with increasing or decreasing fan speed and the number of fans in operation depending on the re-cooling power required. This is determined by the heat transfer fluid exit temperature from the dry cooler unit (and thus the re-cooling fluid supply temperature to the collector field). If solar irradiation and/or the absorber temperature fall to low levels the pumps are sequentially shut off starting with the re-cooling loop. Measurements for the control system are based on temperature and irradiation values averaged over a period of 10 minutes to avoid erratic stop and start operations.

\section{Absorption}

The absorption mode starts with the cool down phase (or 'swap') where the collector loop R pump is started when solar irradiation is low (signifying sunset). Various security algorithms are employed to avoid starting the flow of fluid if collector temperature is above a pre-defined level. Intrinsically included in the cool down phase is the heat recovery phase, where, if fluid temperatures leaving the collector field from the circulation loop R are sufficiently high (compared to the heating demand/hot store temperatures), the thermal energy is channelled to and stored in the hot store by running the heating loop and heat storage loop pumps. After the cool down phase the collector loop C pump starts and the re-cooling loop pump is started in case the heating loop is unable to reject all the heat supplied by the collector loop R. After the maximum amount of heat has been tapped the system shifts into the heat rejection phase, in this operational phase the circulation loop and re-cooling loop pumps are run simultaneously to remove heat from the reactor of the sorption collectors and lower the temperature to a level where cooling can start to be delivered via the condenser/evaporator components of the sorption collectors. As in the desorption phase the dry cooler fan operations are staged up and down 
depending on the difference between the fluid temperaure and the outdoor temperature. The final (and longest) phase of the absorption mode is characterised by the delivery of cooling to the cold store via the cooling loop and cold storage loop pumps which are activated simultaneously with the collector loop C pump. Cooling delivery/storage continues until the collectors are fully absorbed (i.e. all water from the condenser/evaporator has moved over to the reactor) or no more energy can be stored, after which all pumps are switched off and the system shifts into stand-by waiting for the following day's desorption sequence.

All fluid loop temperature measurements are made by PT1000 resistance sensor probes placed directly into the flow stream while flow rates are measured directly by the Magna pumps. In addition two high performing flow sensors (Kamstrup and GWF) are installed to measure input and output flow on the cold tanks. Global irradiation in the collector plane and diffuse irradiation in the horizontal plane are measured by CMP6 and CMP3 pyranometers from Kipp \& Zonen respectively. The diffuse pyranometer is shaded by a CM121B shadow ring from Kipp \& Zonen.

Electrical power consumed by the installation is measured via a power meter installed in the main system control cabinet that measures all pumps, fans and control electronics in the installation. All data were recorded with a datalogger at a 1 minute sample interval.

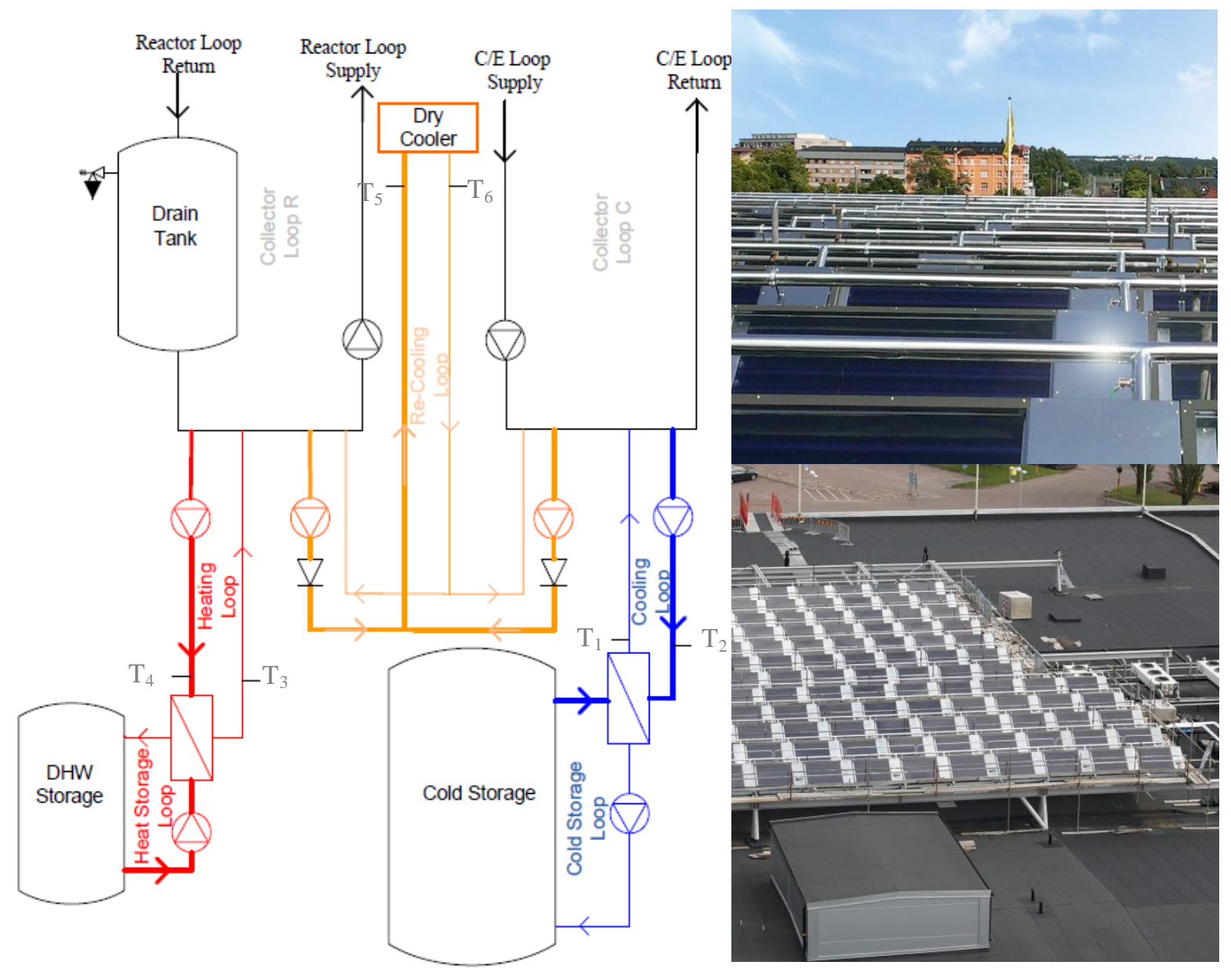

Fig. 3: Left - System schematic of large-scale installation showing temperature measurement points (collectors not shown). Right photographs of the double glazed flat plate sorption integrated collectors in the large-scale installation.

\section{Experimental Results}

In order to characterise the collector and system performance a set of key performance indicators were calculated. Cooling energy delivered to the cold store $\left(\mathrm{E}_{\mathrm{cool}}\right)$, heating energy delivered to the hot store for domestic hot water purposes $\left(\mathrm{E}_{\mathrm{DHW}}\right)$, and electrical coefficient of performance $\left(\mathrm{COP}_{\mathrm{el}}\right)$. Additionally, the solar coefficient of performance $\left(\mathrm{COP}_{\text {solar }}\right)$ i.e., the quotient of cooling energy delivered to solar insolation on the installation was calculated. $\mathrm{COP}_{\text {solar }}$ should not be confused with thermal $\mathrm{COP}\left(\mathrm{COP}_{\text {cool }}\right)$ which for absorption chiller driven systems doesn't include the efficiency of the collectors (and hot store). In the integrated sorption collectors, thermal efficiency cannot be easily calculated since the absorption chiller is effectively in the solar 
collector and is directly exposed to solar radiation. Given that the primary goal of solar cooling systems is to reduce electricity consumption, being able to compare the solar thermal cooling system to a conventional electric vapour compression system is pertinent. The table below summarises the equations used to calculate the key performance indicators.

Tab. 1: Equations used to calculate key performance parameters

\begin{tabular}{|ll|l|}
\hline$\dot{\mathrm{Q}}_{\text {cool }}=\mathrm{c}_{\mathrm{p}} \dot{\mathrm{m}}\left(\mathrm{T}_{1}-\mathrm{T}_{2}\right)$ & [During absorption] & eq. 1 \\
\hline$\dot{Q}_{D H W}=c_{p} \dot{m}\left(T_{3}-T_{4}\right)$ & [During swap and absorption] & eq. 2 \\
\hline$\dot{Q}_{h s-c e}=c_{p} \dot{m}\left(T_{5}-T_{6}\right)$ & [During desorption] & eq. 3 \\
\hline$\dot{Q}_{h s-r e}=c_{p} \dot{m}\left(T_{5}-T_{6}\right)$ & [During absorption] & eq. 4 \\
\hline $\mathrm{E}_{\text {total }}=\mathrm{E}_{\mathrm{hs}-\mathrm{ce}}+\mathrm{E}_{\mathrm{cool}}+\mathrm{E}_{\mathrm{hs}-\mathrm{ce}}+\mathrm{E}_{D H W}$ & eq. 5 \\
\hline$\eta_{\text {total }}=\frac{E_{\text {total }}}{H A}$ & eq. 6 \\
\hline COP $_{\text {solar }}=\frac{E_{\text {cool }}}{H A}$ & eq. 7 \\
\hline Cooling Energy Index $=\frac{\mathrm{E}_{\text {cool }}}{\mathrm{A}}$ & eq. 8 \\
\hline Cooling Power Index $=\frac{\dot{Q}_{\text {cool }}}{A}$ & eq. 9 \\
\hline COP $P_{\text {el }}=\frac{E_{\text {cool }}}{E_{\text {el }}}$ & eq. 10 \\
\hline
\end{tabular}

\subsection{Laboratory-Scale Installation Measurements}

Over a period of 2 months, the laboratory-scale-4-collector installation was monitored and performance measured and summarised. From the experimental data it was seen that days with total solar insolation below $3.0 \mathrm{kWh} \mathrm{m}^{-2} \mathrm{day}^{-1}$ provided less than $0.1 \mathrm{kWh} \mathrm{m}^{-2} \mathrm{day}^{-1}$ of useful cooling energy so were omitted from the performance analysis of the collectors, and this figure taken as the lower limit for collector operation. Additionally, for insolation levels $3.6 \mathrm{kWh} \mathrm{m}^{-2} \mathrm{day}^{-1}$ and above the cooling energy delivered was proportional to the solar insolation level and cooling power was constant at constant cooling and re-cooling temperature levels.

Tab. 2 Average system parameter values during outdoor laboratory-scale evaluation of the sorption integrated solar collectors

\begin{tabular}{|l|c|c|}
\hline \multicolumn{1}{|c|}{ Parameter } & Desorption & Absorption \\
\hline Average Reactor HEX Supply Temperature $\left[{ }^{\circ} \mathrm{C}\right]$ & - & 25.9 \\
\hline Average C/E HEX Supply Temperature $\left[{ }^{\circ} \mathrm{C}\right]$ & 24.7 & 12.1 \\
\hline Reactor HEX Loop Fluid Flow Rate $\left[\right.$ litre s $\left.{ }^{-1}\right]$ & - & 0.09 \\
\hline Condenser/Evaporator HEX Loop Fluid Flow Rate $\left[\right.$ litre s $\left.{ }^{-1}\right]$ & 0.07 & 0.07 \\
\hline
\end{tabular}

Tab.3: Measurement results of laboratory-scale solar heating and cooling system using integrated sorption collectors over a 40 day test period.

\begin{tabular}{|l|c|c|c|}
\hline \multicolumn{1}{|c|}{ Performance Parameters } & Max. & Min. & Ave. \\
\hline Solar Cooling COP $\left(\mathrm{COP}_{\text {solar }}\right)$ & 0.25 & 0.10 & 0.19 \\
\hline Cooling Power Index $\left[\mathrm{kW} \mathrm{m}^{-2}\right]$ & 0.20 & 0.09 & 0.15 \\
\hline Cooling Energy Index $\left[\mathrm{kWh} \mathrm{m}^{-2} \mathrm{day}^{-1}\right]$ & 1.44 & 0.34 & 0.97 \\
\hline Daily Solar Insolation $(\mathrm{H})\left[\mathrm{kWh} \mathrm{m}^{-2} \mathrm{day}^{-1}\right]$ & 6.30 & 3.11 & 4.86 \\
\hline Heating Energy for DHW $\left(\right.$ above $\left.\left.40^{\circ} \mathrm{C}\right)\left[\mathrm{kWh} \mathrm{m}^{-2} \mathrm{day}^{-1}\right)\right]$ & 0.30 & 0.00 & 0.17 \\
\hline $\begin{array}{l}\text { Thermal Energy Dissipated to the Environment }\left(\mathrm{Re}^{2} \text {-Cooling) }\left[\mathrm{kWh} \mathrm{m}^{-1}\right.\right. \\
\left.\text { day }^{-1}\right]\end{array}$ & 4.1 & 1.0 & 2.7 \\
\hline Total Efficiency $\left(\eta_{\text {total }}\right)$ & 1.00 & 0.40 & 0.76 \\
\hline
\end{tabular}

\subsection{Large-Scale Installation Measurements}

The large-scale installation was completed the final week of June 2014, and set to operate in the simplest mode of its control possibilities. That is, pumps were operated at constant head and rudimentary control parameters used for mode modulation. Desorption start radiation level was set at $300 \mathrm{Wm}^{-2}$ and absorber temperature to $50^{\circ} \mathrm{C}$, these settings were chosen based on experience from the laboratory-scale installation but still needed to 
be optimised for the current installations characteristics. The stop and start temperatures of each group of fans for the dry cooler were taken from system simulation in TRNSYS as well as stop and start times and temperatures for each collector loop.

Fourteen (14) days of data were obtained for non-optimised system operation from July 11 to July 24, 2014. During this period only 110 collectors were in operation. Cooling and heating energy delivered to the hot and cold stores were used for calculating system performance indicators.

Tab. 4: Average system parameter values during outdoor large-scale evaluation of the sorption integrated solar collectors

\begin{tabular}{|l|c|c|}
\hline \multicolumn{1}{|c|}{ Parameter } & Desorption & Absorption \\
\hline Average Reactor HEX Supply Temperature $\left[{ }^{\circ} \mathrm{C}\right]$ & - & 26.5 \\
\hline Average C/E HEX Supply Temperature $\left[{ }^{\circ} \mathrm{C}\right]$ & 33.5 & 13.9 \\
\hline Reactor HEX Loop Fluid Flow Rate $\left[\right.$ litre s s $\left.{ }^{-1}\right]$ & - & 1.97 \\
\hline Condenser/Evaporator HEX Loop Fluid Flow Rate $\left[\right.$ litre s $\left.{ }^{-1}\right]$ & 1.93 & 1.93 \\
\hline
\end{tabular}

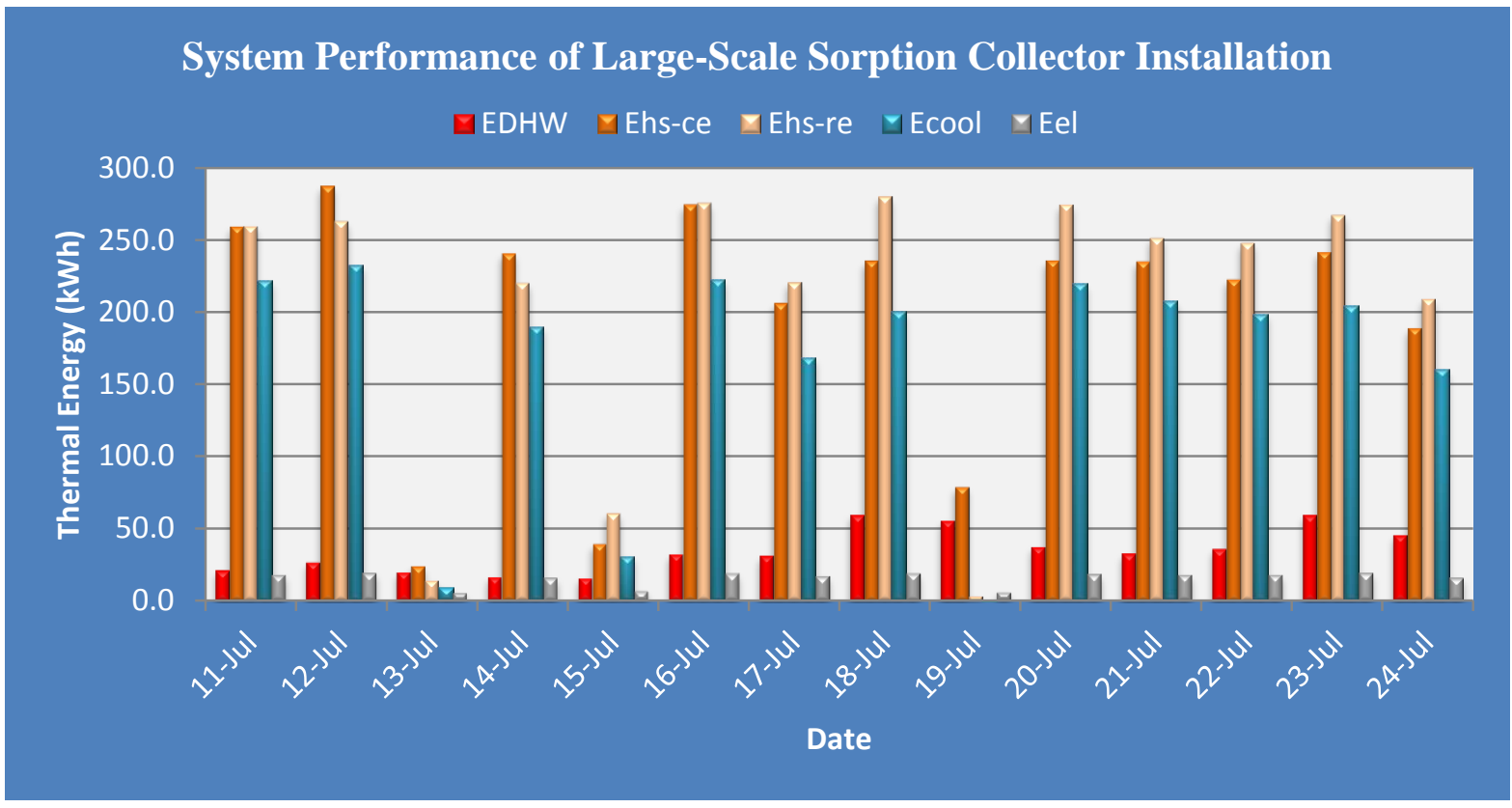

Fig. 4: Daily system performance of the large-scale sorption collector installation.

Tab. 5: Measurement results for large-scale solar heating and cooling installation using integrated sorption collectors over the first 8 days of the 14 day test period.

\begin{tabular}{|c|c|c|c|c|}
\hline Date & $\mathbf{H}\left(\mathbf{k W h m}^{\mathbf{- 2}}\right)$ & $\mathbf{C O P}_{\text {solar }}$ & $\boldsymbol{\eta}_{\text {total }}$ & $\mathbf{C O P}_{\text {el }}$ \\
\hline $11 / 07 / 2014$ & 7.1 & 0.20 & 0.70 & 11.7 \\
\hline $12 / 07 / 2014$ & 7.9 & 0.19 & 0.67 & 11.1 \\
\hline $13 / 07 / 2014$ & 2.7 & 0.02 & 0.16 & 13.6 \\
\hline $14 / 07 / 2014$ & 6.0 & 0.21 & 0.73 & 10.9 \\
\hline $15 / 07 / 2014$ & 3.0 & 0.07 & 0.32 & 7.8 \\
\hline $16 / 07 / 2014$ & 7.5 & 0.20 & 0.71 & 9.5 \\
\hline $17 / 07 / 2014$ & 6.5 & 0.17 & 0.63 & 11.6 \\
\hline $18 / 07 / 2014$ & 7.4 & 0.18 & 0.69 & 9.4 \\
\hline
\end{tabular}


Tab. 6: Measurement results for large-scale solar heating and cooling installation using integrated sorption collectors over the last 6 days of a 14 day test period along with average results over the entire 14 day period (blue).

\begin{tabular}{|l|c|c|c|c|}
\hline \multicolumn{1}{|c|}{ Date } & $\mathbf{H}\left(\mathbf{k W h m}^{-2}\right)$ & $\mathbf{C O P}_{\text {solar }}$ & $\boldsymbol{\eta}_{\text {total }}$ & $\mathbf{C O P}_{\text {el }}$ \\
\hline $19 / 07 / 2014^{1}$ & 4.9 & 0.00 & 0.00 & 0.0 \\
\hline $20 / 07 / 2014$ & 7.7 & 0.19 & 0.65 & 7.7 \\
\hline $21 / 07 / 2014$ & 7.6 & 0.18 & 0.63 & 11.8 \\
\hline $22 / 07 / 2014$ & 7.5 & 0.17 & 0.62 & 11.8 \\
\hline $23 / 07 / 2014$ & 7.5 & 0.18 & 0.67 & 11.1 \\
\hline $24 / 07 / 2014$ & 6.0 & 0.17 & 0.66 & 11.8 \\
\hline Average & 6.4 & 0.16 & 0.60 & 10.6 \\
\hline
\end{tabular}

Tab. 7: Measurement results of large-scale solar heating and cooling system using integrated sorption collectors over the 14 day test period.

\begin{tabular}{|l|c|c|c|}
\hline \multicolumn{1}{|c|}{ Performance Parameters } & Max. & Min. & Ave. \\
\hline Solar Cooling COP $\left(\mathrm{COP}_{\text {solar }}\right)$ & 0.21 & 0.02 & 0.17 \\
\hline Cooling Power Index $\left[\mathrm{kW} \mathrm{m}^{-2}\right]$ & 0.25 & 0.14 & 0.19 \\
\hline Cooling Energy Index $\left[\mathrm{kWh} \mathrm{m}^{-2} \mathrm{day}^{-1}\right]$ & 1.52 & 0.06 & 1.16 \\
\hline Daily Solar Insolation $(\mathrm{H})\left[\mathrm{kWh} \mathrm{m}^{-2} \mathrm{day}^{-1}\right]$ & 7.9 & 2.7 & 6.7 \\
\hline Heating Energy for DHW $\left.\left[\mathrm{kWh} \mathrm{m}^{-2} \mathrm{day}^{-1}\right)\right]$ & 0.39 & 0.10 & 0.21 \\
\hline $\begin{array}{l}\text { Thermal Energy Dissipated to the Environment }(\text { Re-Cooling })\left[\mathrm{kWh} \mathrm{m}^{-1}\right. \\
\left.\text { day }^{-1}\right]\end{array}$ & 3.60 & 0.25 & 2.87 \\
\left.\hline${\text { Total Efficiency }\left(\eta_{\text {total }}\right)}\right)$ & 0.73 & 0.16 & 0.63 \\
\hline Electrical COP $\left(\mathrm{COP}_{\mathrm{el}}\right)$ & 12.6 & 1.7 & 10.6 \\
\hline
\end{tabular}

\section{Discussion}

For the two demonstration systems installed, laboratory-scale and large-scale, average solar cooling COP is in the range of 0.17 to 0.19 and electrical coefficient of performance in the range of 10 to 12 . This stands well in comparison to previous solar cooling installations. Three installations measured and examined within the Solarthermie 2000plus with respective sizes 20,680 and 1050kW of installed cooling power are all in the range of 3 to 6 in electrical COP and 0.40 to 0.56 in thermal COP (COP $\left.{ }_{\text {cool }}\right)$ (Wiemken et. al., 2013). Comparable results have been obtained by multiplying the average thermal COP with the average measured collector efficiency, including losses from the hot store, for the months of June through August for the Solarthermie installations. The results are shown in Tab. 8 .

Tab. 8: Comparison of measured solar thermal cooling installations with the large-scale demonstration installation measured in this study (blue) (Wiemken et. al., 2013).

\begin{tabular}{|l|c|c|c|}
\hline \multicolumn{1}{|c|}{ Installation } & COP $_{\text {cool }}$ & $\mathbf{C O P}_{\text {solar }}$ & $\mathbf{C O P}_{\text {el }}$ \\
\hline Rottweil $680 \mathrm{~kW}$ & 0.56 & 0.21 & 5.80 \\
\hline Festo $1050 \mathrm{~kW}$ & 0.43 & 0.17 & 2.95 \\
\hline Butzbach $20 \mathrm{~kW}$ & 0.53 & 0.13 & 4.82 \\
\hline Large-scale installation $40 \mathrm{~kW}$ & - & 0.17 & 10.60 \\
\hline Large-scale installation $40 \mathrm{~kW}$ (including cold store) & - & 0.14 & 8.40 \\
\hline
\end{tabular}

The losses from the hot store, in the case of the conventional solar cooling installations, were included in the collector efficiency since they are an integral part of the solar cooling system. Similarly it can be said that the cold store is an integral part of the sorption collector system (depending on the application) since the cooling is delivered at night time, and consequently the losses from the cold store should also be included for fair comparison. Doing this the $\mathrm{COP}_{\text {solar }}$ is actually lower for the integrated system whereas the $\mathrm{COP}_{\mathrm{el}}$ is still

\footnotetext{
${ }^{1}$ Data from July 19 not included in calculation of average values due to a control error where absorption mode was not initiated.
} 
significantly higher. This however seems to be in line with the conclusions of Hallström, et al. (2014) that the main performance indicator for a sorption integrated collector system is the collector technology (i.e. the type of solar thermal collector into which the sorption modules are integrated). Where, in this case, vacuum tube technology were found to perform better than enhanced flat plate technology. All compared installations in the Solarthermie 2000plus study used vacuum tube collectors whereas the large-scale installation is done with double-glazed flat plate collectors. In addition, the heat rejection for the sorption integrated collector system is done by a dry cooler whereas the Solarthermie installations used wet cooling towers. Considering this, the results presented in this paper for the two measured systems with sorption integrated solar thermal collectors are quite promising. It should be noted that for the tests carried out in this paper neither the laboratory-scale nor the large-scale installations have optimised control strategies to balance thermal performance and electrical performance. This therefore leaves opportunity for even greater thermal and electrical performance if pump and fan operations can be fine-tuned depending on the operational conditions. Higher average COPs with and without thermal storage are therefore expected after such optimisations, and this will be the principal focus of future work.

Additionally for the large-scale installation the proportion of energy recovered for domestic hot water $\left(\mathrm{E}_{\mathrm{DHW}}\right)$ was unexpectedly low, which is most probably due to a non-optimised time for entering the swap mode. In this type of system if swap is started too early (before all useful solar energy is absorbed) it could sacrifice cooling energy potential but if started too late (after the collectors have cooled significantly due to radiant losses after sunset or an extended period of low irradiation) the recovery of thermal energy above $50^{\circ} \mathrm{C}$ will be diminished.

Another major operation challenge has been in the large-scale system the heat transfer fluid pressure difference between hot collectors during the day and cold collectors during the night. The installation was commissioned as a pressure-less system as is normal practice for drain-back systems. During desorption the air inside the collectors heats up and expands and hence raises the pressure of the entire system. Since the plumbing is not completely air tight, some air leaks out during the day, leading to a slight under pressure during absorption. At night air will hence be sucked back into the system, but since the condenser/evaporator circuit is at the same height as the reactor circuit air will consequently get sucked into this circuit as well. Air inside the condenser/evaporator circuit hinders the flow through the collectors and leads to lower heat transfer coefficients, elevated thermal losses and/or the stagnation of the collectors as the vapour inside the sorption modules is not allowed to condense during desorption. A suggested solution to this problem is to separate the two circuits by means of a heat exchanger separating the reactor circuit from the rest of the installation. Thus leaving the pressure-less drain back system as small as possible and eliminating the risk of air from the drain back finding its way to the dry cooler. This would give higher heat rejection temperatures during absorption, but on the other hand ensures good heat transfer characteristics and more stable and robust performance of the system.

On the techno-economic front, apart from the sorption modules employed in the collectors, only standard components have been employed in both the laboratory and large-scale installations. For the large-scale installation, equipment was dimensioned by a direct scaling up of that used for the laboratory-scale system, along with a dry cooler being used for heat rejection. Given that cooling powers scale linearly depending on collector aperture area component dimensioning can thus be done based on simple formulae according to the number of collectors in the installation (i.e. total aperture area), this gives rise to the possibility of producing 'plug-and-play' kits for a range of system sizes with minimal engineering and special knowledge requirements to have a well performing solar heating and cooling system.

\section{Conclusions}

For the two demonstration systems installed, laboratory-scale and large-scale, average solar cooling COP is in the range of 0.17 to 0.19 . This stands well in comparison to previous solar thermal cooling installations. Both of the systems studied in this paper exhibited similar thermal performance which might suggest that system performance isn't delimited by system size giving rise to the possibility of producing 'plug-and-play' kits for a range of system sizes with minimal engineering and special knowledge requirements to obtain a well performing solar heating and cooling system. For the large-scale installation with non-optimised control strategies an average electrical coefficient of performance of 10.6 (without storage) and 8.4 (with storage) were measured. This is significantly higher than other state-of-the-art solar thermal cooling installations measured in the Solarthermie 2000plus programme. Higher average electrical COPs with and without storage are expected to be achievable if the system control is fully optimised. This will be the principal focus of future work. 


\section{Nomenclature}

HEX - Heat exchanger

$\mathrm{C} / \mathrm{E}-\mathrm{Condenser/Evaporator}$

$\mathrm{COP}_{\mathrm{el}}-$ Electrical coefficient of performance

HVAC - Heating Ventilation and Air Conditioning

$\dot{\mathrm{m}}$ - mass flow rate of heat transfer fluid $(\mathrm{kg} / \mathrm{s})$

A - total collector aperture area $\left(\mathrm{m}^{2}\right)$

$\mathrm{COP}_{\text {cool }}$ - thermal cooling coefficient of performance (quotient of thermal energy into a thermal heat pump and cooling energy output)

$\mathrm{COP}_{\text {solar }}$ - solar coefficient of performance

$\mathrm{c}_{\mathrm{p}}$ - specific heat capacity at constant pressure of heat transfer fluid $\left(\mathrm{kJkg}^{-1 \circ} \mathrm{C}^{-1}\right)$

$\mathrm{H}$ - incident insolation in the plane of the collector $\left(\mathrm{kWhm}^{-2}\right)$

$\dot{\mathrm{Q}}_{\text {cool }}$ - average cooling power delivered during absorption mode $(\mathrm{kW})$

$\dot{\mathrm{Q}}_{\text {heat }}$ - average thermal power recovered for DHW during swap phase and the absorption mode $(\mathrm{kW})$

$\dot{\mathrm{Q}}_{\mathrm{hs}-\mathrm{ce}}-$ average thermal power rejected to the heat sink during the desorption mode (condensation power

dissipated) (kW)

$\dot{\mathrm{Q}}_{\mathrm{hs}-\mathrm{re}}-$ average thermal power rejected to the heat sink during the absorption mode $(\mathrm{kW})$

$\mathrm{E}_{\mathrm{cool}}-$ cooling energy during absorption phase - time integrated energy value of $\mathrm{Q}_{\text {cool }}$ over the entire absorption mode (kWh)

$\mathrm{E}_{\mathrm{el}}-$ electrical energy consumed by the installation $(\mathrm{kWh})$

$\mathrm{E}_{\mathrm{DHW}}$ - heating energy delivered to domestic hot water - time integrated energy value of $\dot{\mathrm{Q}}_{\text {heat }}$ during time period for swap phase and absorption mode $(\mathrm{kWh})$

$\mathrm{E}_{\mathrm{hs}-\mathrm{ce}}$ - heating energy during desorption mode - time integrated energy value of $\dot{\mathrm{Q}}_{\mathrm{hs} \text {-ce }}$ over the entire time period for absorption (condensation energy dissipated) $(\mathrm{kWh})$

$\mathrm{E}_{\mathrm{hs}-\mathrm{re}}$ - heating energy during absorption mode - time integrated energy value of $\dot{\mathrm{Q}}_{\mathrm{hs}-\mathrm{re}}$ (condensation energy dissipated) $(\mathrm{kWh})$

$\mathrm{T}_{1}$ - average supply temperature to condenser/evaporator loop $\left({ }^{\circ} \mathrm{C}\right)$

$\mathrm{T}_{2}$ - average return temperature from condenser/evaporator loop $\left({ }^{\circ} \mathrm{C}\right)$

$\mathrm{T}_{3}$ - average return temperature from heat store heat exchanger $\left({ }^{\circ} \mathrm{C}\right)$

$\mathrm{T}_{4}$ - average supply temperature to the heat store heat exchanger $\left({ }^{\circ} \mathrm{C}\right)$

$\mathrm{T}_{5}$ - average supply temperature to the heat $\operatorname{sink}\left({ }^{\circ} \mathrm{C}\right)$

$\mathrm{T}_{6}-$ average return temperature from the heat $\operatorname{sink}\left({ }^{\circ} \mathrm{C}\right)$

\section{References}

Blackman C., Bales C., 2014. Evaluation of a Novel Absorption Heat Pump Module for Solar Cooling Applications, Proceedings from the International Sorption Heat Pump Conference, April 2014.

Füldner G. et al., 2013. KollSorp - Entwicklung eines kollektorintegrierten Sorptionssystems zur solaren Kühlung und Heizungsunterstützung. Proceedings of the 23. Symposium Thermische Solarenergie, OTTI.

Hallström, O., Füldner, G., Spahn H., Schnabel, L., Salg, F., 2013. Development of Collector Integrated Sorption Modules for Solar Heating and Cooling: Performance Simulation, International Conference on Solar Heating and Cooling for Buildings and Industry.

Henning, H.M., 2007. Solar assisted air conditioning of buildings - an overview. Applied Thermal Engineering, vol. $27,10,1734-1749$.

Stryi-Hipp, G., Weiss, W., Mugnier, D., Dias, P., 2012. Strategic Research Priorities for Solar Thermal Technology, European Technology Platform on Renewable Heating and Cooling.

Wiemken E., Elias A.-Petry., 2013. Solarthermie 2000plus: Wissenschaftliche Programmbegleitung und Begleitforschung Solarthermische Gebäudeklimatisierung, German Combined Project 0329605A, Final Report.

Witte, K.T., Morgenstern, A., Henning, H.M., Núñez, T., Schossig, P., 2011, Solar Thermal Cooling Technologies and Market Situation, IEA Heat Pump Centre Newsletter, vol 29, no.1/2011, p.27 - 30.

\section{Acknowledgement}

This work has been carried out via financing from the LIFE+ programme, and under the auspices of the industrial post-graduate school REESBE, the Swedish Knowledge Foundation (KK-stiftelsen), the Swedish Research Council Formas and Löfbergs Lila AB. The authors would like to specially thank Jan Möttönen (Löfbergs Lila AB) and the employees of ClimateWell AB for their valuable contributions in this study. 